ISSN 1392-3196 / e-ISSN 2335-8947

Zemdirbyste-Agriculture, vol. 102, No. 3 (2015), p. 281-288

DOI 10.13080/z-a.2015.102.036

\title{
Albumin content in bread wheat (Triticum aestivum L.) and durum wheat (Triticum durum Desf.) as affected by the environment
}

\author{
Gordana BRANKOVIĆ ${ }^{1}$, Vesna DRAGIČEVIĆ ${ }^{2}$, Dejan DODIG ${ }^{2}$, Desimir KNEŽEVIĆ \\ Borislav KOBILJSKI ${ }^{4}$, Gordana ŠURLAN-MOMIROVIĆ ${ }^{1}$ \\ ${ }^{1}$ University of Belgrade \\ 11000 Belgrade, Serbia \\ E-mail: gbrankovic@agrif.bg.ac.rs \\ ${ }^{2}$ Maize Research Institute "Zemun Polje" \\ 11185 Belgrade, Serbia \\ ${ }^{3}$ University of Priština \\ 38219 Le ak, Serbia \\ ${ }^{4}$ Biogranum Ltd. \\ 21000 Novi Sad, Serbia
}

\begin{abstract}
Albumins or water soluble proteins (wsp) in wheat are important as nutrients containing high content of essential amino acids such as lysine, tryptophan, methionine, and also asparagine, glutamine, arginine, and proline in comparison to storage proteins-glutenins and gliadins. Fifteen bread wheat (Triticum aestivum L.) and 15 durum wheat (Triticum durum Desf.) genotypes were evaluated across six different environments for two years to determine the content of albumins in grains. The purpose of this research was to determine the variability of the albumins content of the tested bread wheat and durum wheat genotypes, effects of environment, genotype and their interaction (GEI) on the trait of interest, heritability in a broad sense, stability, and also to interpret GEI by climatic factors modelling. The statistical procedure included analysis of variance, sites regression and factorial regression. The mean content of albumins was $20.23 \mathrm{~g} \mathrm{~kg}^{-1}$ in bread wheat and $23.12 \mathrm{~g} \mathrm{~kg}^{-1}$ in durum wheat. Environment followed by GEI was the most important in determining albumins content. The heritability in a broad sense was low, i.e. $31.3 \%$ for bread wheat and only $2.4 \%$ for durum wheat. GEI for the albumins content was explained with the efficacy of $94.7 \%$ and $94.2 \%$ of sum of squares, for bread wheat and durum wheat, respectively, by the following models: mean temperature in May, winter moisture reserves, minimum temperature in April and March for bread wheat; and precipitation sum in April, sunshine hours sum in March, maximum temperature in May, and winter moisture reserves for durum wheat. The simultaneous selection for high albumins content and good stability proved to be possible for bread wheat genotypes, but less for durum wheat genotypes due to unsatisfactory stability.
\end{abstract}

Key words: factorial regression, genotype $\times$ environment interaction, grain quality, heritability, multi-environment trial.

\section{Introduction}

The common (bread) wheat (Triticum aestivum L.) and durum wheat (Triticum durum Desf.) grains contain two kinds of major proteins: non-storage and storage proteins. The non-storage proteins, also named metabolic proteins, include water soluble proteins albumins and salt soluble globulins, accounting for 15$20 \%$ of all of the grain proteins (Piergiovanni, 2007). The storage proteins consist of glutenins (soluble in dilute acids or alkali) and gliadins (soluble in 70-90\% aqueous ethanol), which provide visco-elasticity and extensibility to dough. Albumins are significant from the nutritional

viewpoint, because they contain high content of essential amino acids such as lysine, tryptophan, methionine, and also a higher content of asparagine, glutamine, arginine, and proline compared to the gluten (Koehler, Wieser, 2013). They take part in the cell biochemical, physiological and regulatory functions as constitutive, and metabolic proteins, and also as inhibitors of insect and fungal pathogens (Muralikrishna, Nirmala, 2005; Koehler, Wieser, 2013). Albumins also play a nutritive role during germination of seeds, as well as in starch digestion and regulation of the starch metabolism and 
osmotic pressure (Piasecka-Kwiatkowska et al., 2007). Their localization is in the aleurone layer, embryo, pericarp and slightly in the endosperm. Albumins are controlled by genes on different homeologus chromosomes: $1 \mathrm{~A}$, 1B, 1D, 3BS, 3DS, 4DL, 4BS, 7A, 7B and 7D (Yu et al., 2013). They can serve as good biochemical markers for genetic studies and plant breeding and also as sources of resistance to insects for creating transgenic plants (Bezerra et al., 2014).

Different ratio of wheat proteins fractions is dependent on the genotype and environmental factors such as climate, soil, cropping practices and ameliorative measures (Yan et al., 2007). Climate and meteorological conditions, among other factors, cause GEI and modify plant responses, determining the quantity and the quality of the production (Garrido-Lestache et al., 2004; Marta et al., 2011). The effect of seasonal climate variability on wheat yields is adequately described (Palosuo et al., 2011), but there is less information in regard to grain quality. The knowledge of the influence of the environmental factors on protein quality may be beneficial for grain buyers and millers when choosing adequate production environments for the acquisition of quality grain without cultivar identification.

The aim of this research was to determine the effects of environment, genotype and their interaction on the variability of albumins content of bread wheat and durum wheat, heritability in a broad sense, stability, and also to dissect GEI by climatic factors as causers, from the multi-environment trial.

\section{Materials and methods}

Plant material, experimental design and field trials. The plant material used for the field trials consisted of 15 bread wheat (Triticum aestivum L. ssp. vulgare) and of 15 durum wheat (Triticum durum Desf.) genotypes. The selection of the genotypes was made from the GeneBank of Institute of Field and Vegetable Crops in Novi Sad, and from the GeneBank of the Maize Research Institute "Zemun Polje" in Belgrade, Serbia. The names, codes and country of origin of used bread wheat genotypes are: 'Žitarka' (P1), Croatia, 'Stephens' (P2), USA, 'Renan' (P3), France, 'Caldwell' (P4), USA, ‘Abe' (P5), USA, ‘Auburn' (P6), USA, 'Frankenmuth' ( P7), USA, 'Apache' (P8), France, ZP AU 12 (P9), Macedonia, 'Marija' (P10), Croatia, 87/Ip (P11), Serbia, 'Tecumseh' (P12), USA, 'Pobeda' (P13), Serbia, 'Zemunska rosa' (P14), Serbia and 'Ludwig' (P15), Austria. The names, codes and country of origin of used durum wheat genotypes are: 37EDUYT No. 7922 (D1), Mexico, 37EDUYT No. 7896 (D2), Mexico, 37EDUYT No. 7817 (D3), Mexico, 'Varano' (D4), Italy, 37EDUYT No. 7821 (D5), Mexico, 37EDUYT No. 7880 (D6), Mexico, 10/I (D7), Serbia, SOD 55 (D8), Slovakia, 37EDUYT/07 No. 7803 (D9), Mexico, DSP-MD-01 No. 66 (D10), Syria, 34/I (D11), Serbia, 37EDUYT No. 7820 (D12), Mexico, 37EDUYT/07 No. 7857 (D13), Mexico, 37EDUYT/07 No. 7849 (D14), Mexico and 120/I (D15), Serbia. Genotypes from Mexico belong to CIMMYT (International Maize and Wheat Improvement Center), and genotypes from Syria to ICARDA (International Center for Agricultural Research in the Dry Areas) from 37EDUYT (37 $7^{\text {th }}$ Elite Durum Unreplicated Yield Trial) and from DSP-MD-01 (Durum Segregating Populations - Mediterranean Dryland) (season 2000-2001).

The field trials were carried out at the Rimski

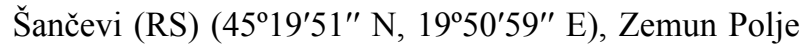

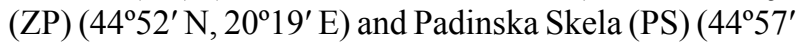
$\left.\mathrm{N}, 20^{\circ} 26^{\prime} \mathrm{E}\right)$ in Serbia, during two growing seasons 2010-2011 (11) and 2011-2012 (12). The field trials were set as a randomized complete block design with four replications. The experimental plot consisted of 5 rows of $1 \mathrm{~m}$ length with an inter-row spacing of $0.2 \mathrm{~m}$. The elementary plot consisted of 3 internal rows of $0.6 \mathrm{~m}^{2}(3$ $\times 0.2 \times 1 \mathrm{~m})$ and plant material within it was used for the analysis. Haplic Chernozem (CHha) is the type of the soil at the RS and ZP sites, while Humic Gleysol (GLhu) is at the PS, specified in accordance with the World refence base (2014). Mineral fertilizers (NPK 15:15:15, MAP monoammonium phosphate) were applied before seeding according to the recommendations, based on the soil chemical properties and available content of $\mathrm{P}, \mathrm{K}$ and $\mathrm{N}$ reserves. Standard anti-fungal protection was applied on seeds and included difenoconazole $30 \mathrm{~g} \mathrm{l}^{-1}$ in 2010-2011 season and tebuconazole $60 \mathrm{~g} \mathrm{l}^{-1}$ in 2011-2012 season. Sowing was done mechanically at the RS and by hand at the PS and the ZP. In the spring, top dressing consisted of the following fertilizers Urea $(46 \% \mathrm{~N})$ at the PS11, PS12, ZP12, KAN $(27 \% \mathrm{~N})$ at the ZP11 and AN (34\% $\mathrm{N})$ at the RS11, ZP11, RS12. The crop was protected adequately against pests and weeds by the appropriate use of pesticides, with their efficacy being monitored.

Climatic conditions during vegetation seasons. Climatic conditions were recorded at the field locations during the months of the growing season, and weather data were provided by the Hydrometeorological Service of Serbia and the Agricultural Corporation Belgrade “Agroekonomik" Institute in Padinska Skela. The average maximum temperature $\left(\mathrm{mxt},{ }^{\circ} \mathrm{C}\right)$, average minimum temperature $\left(\mathrm{mnt},{ }^{\circ} \mathrm{C}\right)$, average mean temperature $(\mathrm{mt}$, ${ }^{\circ} \mathrm{C}$ ), average relative humidity ( $\mathrm{rh}, \%$ ), sunshine hours sum (sh, h) and precipitation sum (pr, mm) for March (1), April (2), May (3) and June (4) were recorded. Also, winter moisture reserves (wmr, $\mathrm{mm}$ ), representing sum of daily precipitation for the period November-February, were calculated. Values of the climatic factors measured at the 6 test-environments are presented in Figure 1.

Chemical analysis of albumins content. Grains were ground with a Laboratory Mill 120 Perten ("Perten", Sweden) (particle size $<500 \mu \mathrm{m}$ ) and flour was used for the analysis. The albumins content was determined by the method of Lowry et al. (1951). Flour samples (4 $x$ $0.25 \mathrm{~g}$ ) were extracted with $10 \mathrm{~mL}$ of double distilled water during $1 \mathrm{~h}$ at the rotatory shaker. The extracts in the quantity of $5 \mathrm{~mL}$ were placed into a centrifuge tubes and then centrifuged with an Eppendorf Centrifuge 5417R ("Eppendorf", Germany) at $12.000 \mathrm{rpm}$ for 15 minutes at $4^{\circ} \mathrm{C}$. In $0.5 \mathrm{ml}$ of supernatant, reagents were added by the 

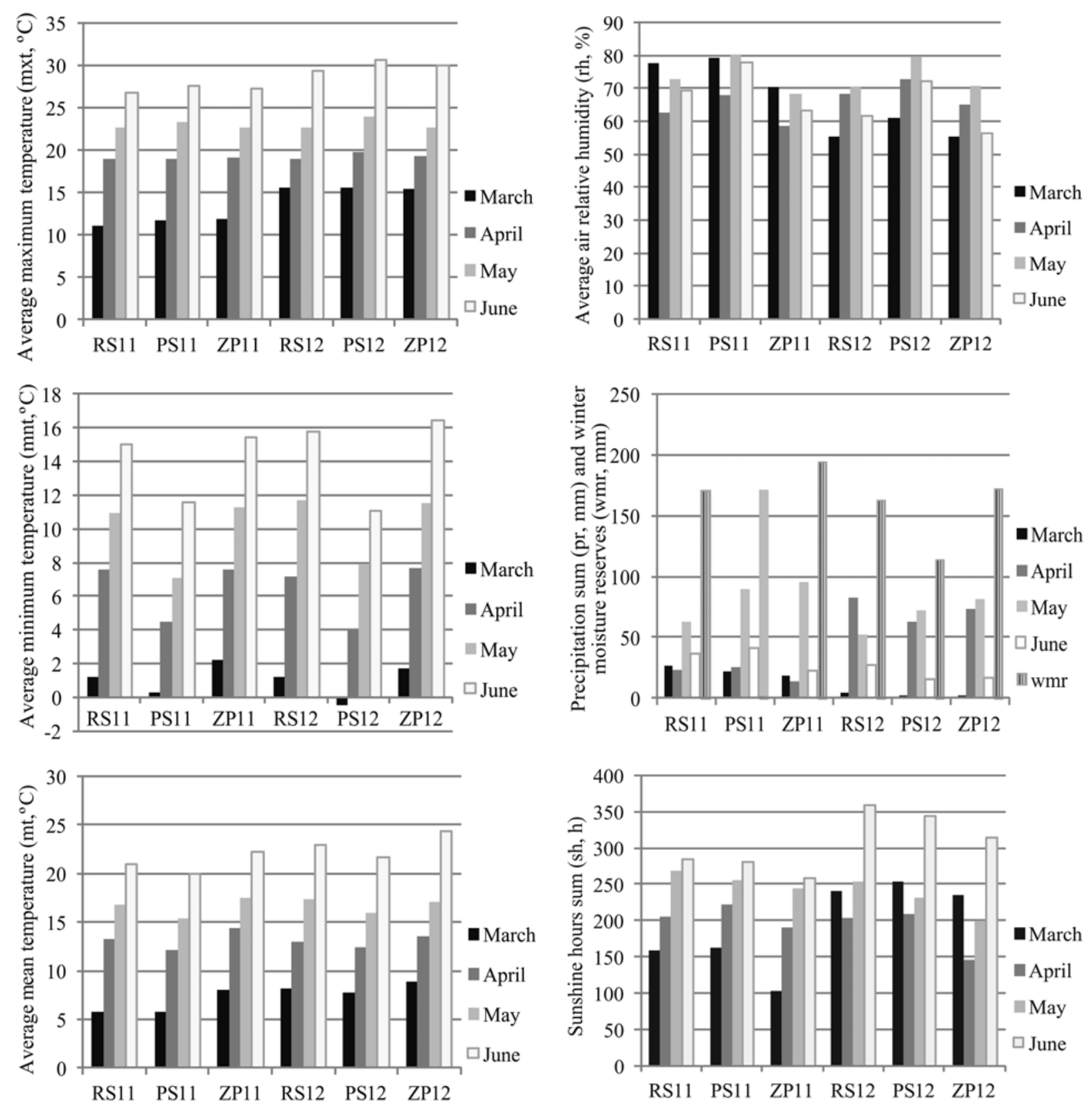

RS - Rimski Šančevi, ZP - Zemun Polje, PS - Padinska Skela

Figure 1. Mean monthly values of the climatic factors measured at the different environments (RS11, RS12, ZP11, ZP12, PS11 and PS12)

following procedure: $2.5 \mathrm{ml}$ of reagent $\mathrm{I}\left(0.5 \% \mathrm{CuSO}_{4} \times\right.$ $5 \mathrm{H}_{2} \mathrm{O}$ was solved in $1 \% \mathrm{Na}, \mathrm{K}$-tartarate and it was added to alkaline solution $\left(2 \% \mathrm{Na}_{2} \mathrm{CO}_{3}\right.$ in $\left.0.1 \mathrm{M} \mathrm{NaOH}\right)$ in the ratio 1:50) and after that $0.25 \mathrm{ml}$ of reagent II (50\% FolinCiocalteu reagent). After colour development, absorbance was read at $\lambda=750 \mathrm{~nm}$ with the spectrophotometer Shimadzu UV-1601 ("Shimadzu", Japan). Albumins content was expressed on the dry mass basis.

Statistical analyses. The two-way fixed analysis of variance (ANOVA) was used for the quantification of the sources of variation, based on random complete block design, with the effects of genotype and environment as fixed ones. Environment represented year $\times$ test location combination. Tukey (HSD) test was performed at the level of significance of 0.05 and served for the significance testing of differences of albumins mean values between genotypes and environments. ANOVA and Tukey (HSD) test were calculated by the use of the STATISTICA 9.0 (StatSoft, 2009). Heritability $\left(\mathrm{h}^{2}\right)$ in a broad sense and coefficients of genetic and phenotypic variance $\left(\mathrm{CV}_{\mathrm{g}}\right.$ and $\left.\mathrm{CV}_{\mathrm{f}}\right)$ were calculated with the variance components estimated according to Falconer (1996). The sites regression (SREG) model (Crossa, Cornelius, 1997) was used to obtain genotype main effects and genotype $\times$ environment interaction (GGE) effects biplots with the average-environment coordination (AEC) view, to show stability of used genotypes. The multiple factorial regressions (van Eeuwijk et al., 1996) included climatic 
variables to determine the degree to which each of these factors influence genotype $\times$ environment interaction for the albumins content. The both data analyses were done within R computing environment (R Core Team, 2013).

\section{Results and discussion}

The mean values for the albumins content of used genotypes of bread wheat and durum wheat across different environments and years of investigation are shown in Table 1.
The average content of albumins was $20.23 \mathrm{~g} \mathrm{~kg}^{-1}$ in bread wheat and $23.12 \mathrm{~g} \mathrm{~kg}^{-1}$ in durum wheat. PiaseckaKwiatkowska et al. (2007) have determined the albumins content of the soft white winter wheat cultivars using the same method, and their average value of $18.40 \mathrm{~g} \mathrm{~kg}^{-1}$ was similar to our obtained value. Analysis of variance showed the significance $(P<0.001)$ of all sources of variation - environment $(\mathrm{E})$, genotype $(\mathrm{G})$ and their interaction (GEI), for albumins content for both, the genotypes of bread wheat and durum wheat (Table 2). The GEI effect compared to the effect of genotype was 3.4 times higher

Table 1. Mean values for the albumins content $\left(\mathrm{g} \mathrm{kg}^{-1}\right)$ across environments and years of investigation of bread wheat (P1-P15) and durum wheat (D1-D15) genotypes

\begin{tabular}{|c|c|c|c|c|c|c|c|c|c|}
\hline \multirow{2}{*}{ Genotype } & \multicolumn{4}{|c|}{$2010-2011$} & \multicolumn{4}{|c|}{$2011-2012$} & \multirow{2}{*}{$\begin{array}{c}\text { Mean for two year } \\
\text { period }\end{array}$} \\
\hline & $\mathrm{RS}$ & $\mathrm{ZP}$ & PS & Mean & $\mathrm{RS}$ & $\mathrm{ZP}$ & PS & Mean & \\
\hline P1 & 23.74 & 21.02 & 14.75 & 19.84 & 20.28 & 20.79 & 18.87 & 19.98 & $19.91 \mathrm{e}$ \\
\hline $\mathrm{P} 2$ & 24.17 & 17.89 & 13.92 & 18.66 & 21.34 & 22.19 & 20.51 & 21.35 & $20.00 \mathrm{e}$ \\
\hline P3 & 24.10 & 16.45 & 11.64 & 17.40 & 19.55 & 21.29 & 20.47 & 20.43 & $18.92 \mathrm{f}$ \\
\hline P4 & 25.93 & 18.65 & 15.32 & 19.97 & 20.40 & 22.05 & 21.22 & 21.22 & $20.60 \mathrm{~d}$ \\
\hline P5 & 22.84 & 13.53 & 13.64 & 16.67 & 21.86 & 18.88 & 20.17 & 20.30 & $18.49 \mathrm{~g}$ \\
\hline P6 & 25.97 & 12.90 & 13.65 & 17.51 & 22.01 & 22.71 & 23.62 & 22.78 & $20.14 \mathrm{e}$ \\
\hline P7 & 25.09 & 15.69 & 13.89 & 18.22 & 22.55 & 21.38 & 24.75 & 22.90 & $20.56 \mathrm{~d}$ \\
\hline P8 & 21.42 & 15.53 & 10.62 & 15.86 & 19.60 & 19.90 & 21.81 & 20.43 & $18.14 \mathrm{~g}$ \\
\hline P9 & 24.24 & 13.52 & 14.65 & 17.47 & 20.87 & 20.37 & 21.73 & 20.99 & $19.23 \mathrm{f}$ \\
\hline P10 & 24.30 & 18.17 & 17.36 & 19.94 & 21.90 & 21.74 & 21.88 & 21.84 & $20.89 \mathrm{~cd}$ \\
\hline P11 & 27.46 & 15.22 & 23.85 & 22.18 & 20.26 & 18.83 & 20.53 & 19.87 & $21.03 \mathrm{c}$ \\
\hline P12 & 24.38 & 17.29 & 22.88 & 21.51 & 20.91 & 21.76 & 21.85 & 21.51 & $21.51 \mathrm{~b}$ \\
\hline P13 & 21.50 & 14.37 & 24.55 & 20.14 & 17.87 & 19.15 & 22.39 & 19.80 & 19.97 e \\
\hline P14 & 31.79 & 16.68 & 19.13 & 22.53 & 22.38 & 22.12 & 25.73 & 23.41 & $22.97 \mathrm{a}$ \\
\hline P15 & 21.44 & 20.16 & 22.91 & 21.50 & 20.96 & 18.49 & 22.86 & 20.77 & $21.14 \mathrm{cb}$ \\
\hline $\begin{array}{c}\text { Mean for } \\
\text { bread wheat }\end{array}$ & $24.56 \mathrm{a}$ & $16.47 \mathrm{e}$ & $16.85 \mathrm{~d}$ & 19.29 & $20.85 \mathrm{c}$ & $20.78 \mathrm{c}$ & $21.89 \mathrm{~b}$ & 21.17 & 20.23 \\
\hline $\mathrm{D} 1$ & 24.26 & 17.91 & 26.27 & 22.81 & 19.45 & 20.87 & 23.62 & 21.32 & $22.06 \mathrm{dc}$ \\
\hline $\mathrm{D} 2$ & 26.78 & 18.56 & 25.91 & 23.75 & 19.28 & 20.47 & 22.89 & 20.88 & $22.31 \mathrm{bc}$ \\
\hline D3 & 26.28 & 17.74 & 24.45 & 22.82 & 19.86 & 22.16 & 19.36 & 20.46 & $21.64 \mathrm{e}$ \\
\hline D4 & 18.99 & 18.20 & 22.96 & 20.05 & 20.53 & 22.09 & 19.86 & 20.83 & $20.44 \mathrm{~h}$ \\
\hline D5 & 19.54 & 20.88 & 27.30 & 22.57 & 23.11 & 24.04 & 20.11 & 22.42 & $22.50 \mathrm{ba}$ \\
\hline D6 & 20.78 & 19.84 & 25.85 & 22.16 & 18.54 & 20.69 & 20.39 & 19.87 & $21.02 \mathrm{gf}$ \\
\hline D7 & 15.39 & 20.83 & 27.25 & 21.15 & 20.08 & 23.79 & 20.09 & 21.32 & $21.24 \mathrm{f}$ \\
\hline D8 & 19.54 & 21.42 & 26.59 & 22.52 & 24.51 & 23.34 & 21.06 & 22.97 & $22.75 \mathrm{a}$ \\
\hline D9 & 17.43 & 16.20 & 21.36 & 18.33 & 20.65 & 22.02 & 20.37 & 21.01 & $19.67 \mathrm{j}$ \\
\hline D10 & 19.44 & 18.25 & 23.92 & 20.54 & 20.91 & 21.29 & 19.95 & 20.72 & $20.63 \mathrm{gh}$ \\
\hline D11 & 18.06 & 11.58 & 24.06 & 17.90 & 20.87 & 24.44 & 21.24 & 22.18 & $20.04 \mathrm{i}$ \\
\hline D12 & 19.66 & 11.75 & 26.01 & 19.14 & 22.10 & 20.74 & 21.85 & 21.56 & $20.35 \mathrm{ih}$ \\
\hline D13 & 20.09 & 19.35 & 21.89 & 20.44 & 23.35 & 22.89 & 22.17 & 22.80 & $21.62 \mathrm{e}$ \\
\hline D14 & 20.30 & 17.18 & 21.77 & 19.75 & 23.81 & 22.32 & 19.96 & 22.03 & $20.89 \mathrm{gf}$ \\
\hline D15 & 21.24 & 15.71 & 24.55 & 20.50 & 23.30 & 26.94 & 19.43 & 23.22 & $21.86 \mathrm{de}$ \\
\hline $\begin{array}{c}\text { Mean for } \\
\text { durum wheat }\end{array}$ & $20.52 \mathrm{e}$ & $17.69 \mathrm{f}$ & $24.68 \mathrm{a}$ & 20.96 & $21.36 \mathrm{c}$ & $22.54 \mathrm{~b}$ & $20.82 \mathrm{~d}$ & 21.57 & 23.12 \\
\hline
\end{tabular}

Notes. Values in the table are expressed on the dry mass basis. Means for the albumins content in columns and rows labelled with the same letter are not significantly different at the 0.05 probability level, compared for bread wheat and durum wheat independently. Tukey (HSD) test was used. RS - Rimski Šančevi, ZP - Zemun Polje, PS - Padinska Skela.

for bread wheat and 4.9 for durum wheat. The hierarchy of influence of sources of variation on the albumins content was established by the use of ANOVA and was the same for both bread wheat and durum wheat: $\mathrm{E}>$ GEI $>\mathrm{G}$, which is consistent with the results of Denčić et al. (2011) and Hadži-Tašković Šukalović et al. (2013). GEI for the albumins content was high $(>30 \%)$, but higher in durum wheat by $18.18 \%$ in comparison to bread wheat. Tukey's (HSD) test showed significant $(P<0.05)$ difference of the albumins content means of bread wheat genotypes between all pairs of environments, except between the RS12 and ZP12, and also between all pairs of environments for durum wheat genotypes (Table 1). The significance of the means difference between genotypes of bread wheat and genotypes of durum wheat is also presented in Table 1. The heritability in a broad 
sense for the albumins content was low and very low in bread wheat and in durum wheat, respectively (Table 2). Genetic and phenotypic variation was also low for both wheat species (Table 2), especially $\mathrm{CV}_{\mathrm{g}}$ for durum wheat, indicating strong environmental influence, and $\mathrm{CV}_{\mathrm{g}}$ and $\mathrm{CV}_{\mathrm{f}}$ were smaller than in other similar studies of bread wheat and durum wheat proteins, as reported by Tao et al. (2012).

Table 2. Two-way ANOVA, broad-sense heritability, coefficients of genotypic and phenotypic variation for the albumins content

\begin{tabular}{|c|c|c|c|c|}
\hline $\begin{array}{l}\text { Source of } \\
\text { variations }\end{array}$ & $\mathrm{df}$ & SS & $\mathrm{SS} \%$ & MS \\
\hline \multicolumn{5}{|c|}{ Bread wheat } \\
\hline Environment (E) & 5 & 23903.34 & 55.8 & $4780.67 * * *$ \\
\hline Genotype (G) & 14 & 4274.96 & 10.0 & $305.35 * * *$ \\
\hline $\mathrm{G} \times \mathrm{E}$ & 70 & 14677.38 & 34.2 & $209.68 * * *$ \\
\hline Error & 252 & 298.45 & & 1.18 \\
\hline $\mathrm{h}^{2} \%$ & \multicolumn{4}{|c|}{31.3} \\
\hline $\mathrm{CV}_{\mathrm{g}} \%$ & \multicolumn{4}{|c|}{3.4} \\
\hline $\mathrm{CV}_{\mathrm{f}}^{\mathrm{s}} \%$ & \multicolumn{4}{|c|}{6.2} \\
\hline \multicolumn{5}{|c|}{ Durum wheat } \\
\hline Environment (E) & 5 & 13723.64 & 49.6 & $2744.73 * * *$ \\
\hline Genotype (G) & 14 & 2371.87 & 8.6 & $169.42 * * *$ \\
\hline $\mathrm{G} \times \mathrm{E}$ & 70 & 11579.16 & 41.8 & $165.42 * * *$ \\
\hline Error & 252 & 280.80 & & 1.11 \\
\hline $\mathrm{h}^{2} \%$ & \multicolumn{4}{|c|}{2.4} \\
\hline $\mathrm{CV}_{\mathrm{g}} \%$ & \multicolumn{4}{|c|}{0.7} \\
\hline $\mathrm{CV}_{\mathrm{f}} \%$ & \multicolumn{4}{|c|}{4.4} \\
\hline
\end{tabular}

$\mathrm{h}^{2}-$ heritability, $\mathrm{CV}_{\mathrm{g}}$ - coefficient of genetic variance, $\mathrm{CV}_{\mathrm{f}}-$ coefficient of phenotypic variance; $\mathrm{df}$ - degrees of freedom, SS - sum of squares, MS - mean square, tested against error mean square; $* * *-P<0.001$

Genotype stability estimation and GEI are specifically interrelated, and genotype is considered to be with the good stability for the trait of interest if the GEI is low. The AEC view of the GGE biplot was used to show the mean performance and stability of albumins for bread wheat and durum wheat genotypes across test-environments. Length of the AEC vector was sufficient to evaluate genotypes on the basis of mean values (Figs. 2-3). By the application of the GGE biplot, $60.34 \%$ of the total $\mathrm{G}+\mathrm{GE}$ variance for albumins content of bread wheat genotypes was interpreted (Fig. 2). Genotypes having above-average values for albumins content were P14, P6, P7, P10 and P12. The genotypes that had below-average values for albumins content were P9, P2, P5, P15, P13, P3, P8 and P1. Genotypes with a mean values close to average were $\mathrm{P} 11$ and $\mathrm{P} 4$. The most stable genotypes were P5, P9 and P14, and they had the most consistent average value for albumins content across all environments. P14 genotype was the most desirable in the simultaneous selection of genotypes with high albumins content and good stability. At the GGE biplot, $56.86 \%$ of the total $\mathrm{G}+\mathrm{GE}$ variance was showed for albumins content for genotypes of durum wheat (Fig. 3). Genotypes having above-average values for albumins content were D1, D2, D6, D8, D7 and D5. The genotypes that had below-average values for albumins were D10,
D15, D4, D13, D14, D12, D11 and D9. Genotype with the average value for the trait of interest close to the total mean value was D3. The most stable genotype was D10 and had the most consistent mean value for albumins content across all environments. None of the examined genotypes of durum wheat can be recommended for the simultaneous selection of genotypes with high content of albumins and good stability, because genotypes with high mean albumins content had unsatisfactory stability. The albumins content in bread wheat grains is not as stable across environments as that of the storage proteins according to Guo et al. (2012).

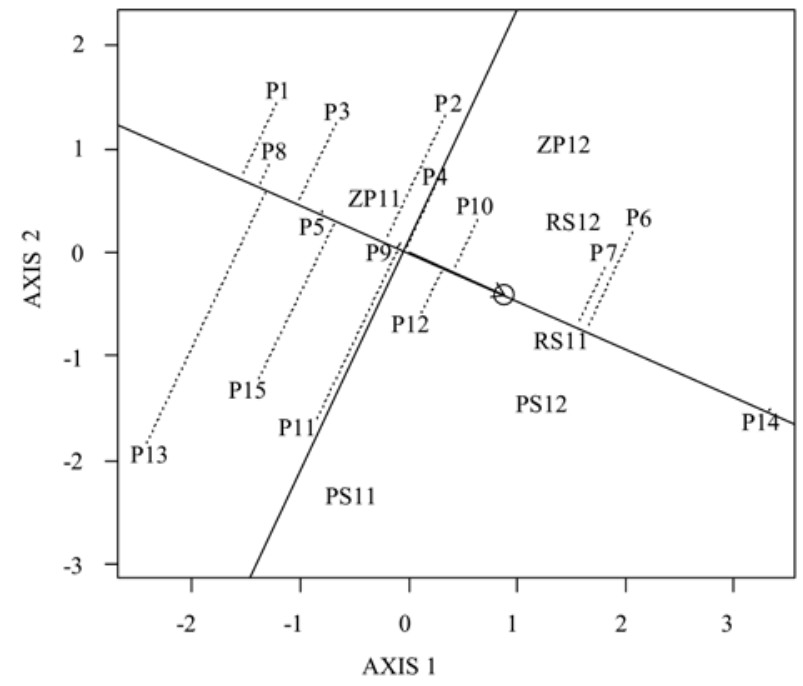

RS - Rimski Šančevi, ZP - Zemun Polje, PS - Padinska Skela; 11-2010-2011 growing season, 12-2011-2012 growing season

Figure 2. The average-environment coordination (AEC) view of the genotype main effects and genotype $\times$ environment interaction (GGE) effects biplot of albumins content for bread wheat genotypes (P1-P15) over tested environments

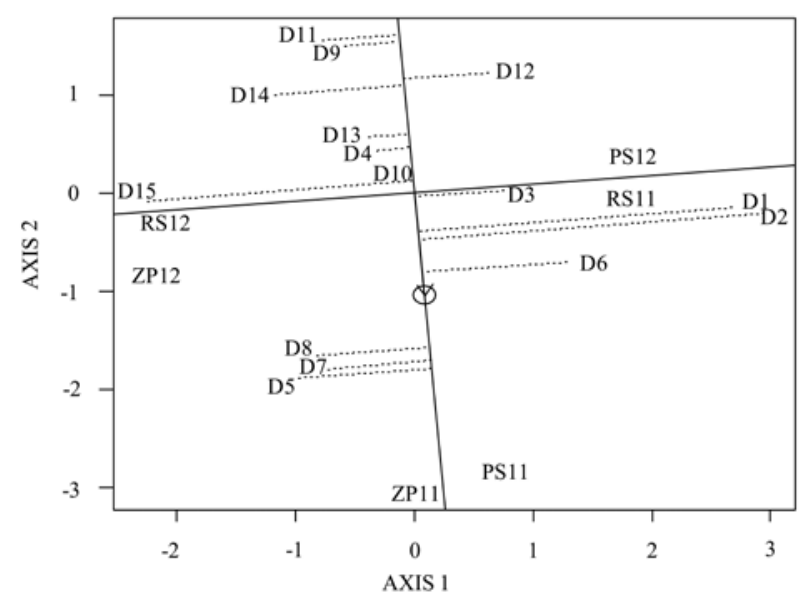

RS - Rimski Šančevi, ZP - Zemun Polje, PS - Padinska Skela; 11-2010-2011 growing season, 12-2011-2012 growing season

Figure 3. The average-environment coordination (AEC) view of the genotype main effects and genotype $\times$ environment interaction (GGE) effects biplot of albumins content for durum wheat genotypes (D1-D15) over tested environments 
The inclusion of all climatic variables to the factorial regression led to the model $(\mathrm{mt} 3, \mathrm{wmr}, \mathrm{mnt} 2$, mnt1) for bread wheat and to the model (pr2, sh1, mxt3, wmr) for durum wheat, which were obtained at the level of significance $(P<0.01)$ (Table 3$)$. The interpreted interaction sum of squares for albumins content was $94.7 \%$ for bread wheat and $94.2 \%$ for durum wheat, using 14 degrees of freedom. Dissecting GEI by including climatic variables per month, the largest percentage of the sum of squares of interaction was obtained in April $(92.9 \%)$, and the lowest in March and May (85.5\% and $85.5 \%$ ) for bread wheat. Pan et al. (2006) found that the average daily temperature, the total sunshine hours and the sum of precipitation are the most important meteorological parameters involved in the determination of protein content in wheat, which is in accordance with our results. During April the stem elongation occurred, as the most intensive phase of plant growth, when the leaf area increased to five times compared to tillering, and when stages of organogenesis led to the formation of the number of the flowers and their fertility. Flag leaves in wheat, formed at the end of the stem elongation phase, are important part of source - sink relation through photo assimilate partitioning and amino acid remobilization (Kumari, 2011). In March, April and May, the most important climatic variable contributing to the GEI for albumins content was mean temperature $(32.1,32.4$ and $42.3 \%$ ), and also relative humidity $(40.1 \%)$ in June for bread wheat (Table 3 ). The largest percentage of the sum of squares of interaction for durum wheat was in March $(94.0 \%)$, during tillering phase, and the lowest was in June $(73.0 \%)$. The most important climatic variable that contributed to the GEI was the relative humidity $(29.6 \%)$ in March, and also precipitation (31.8\%) in April, sunshine hours $(21.8 \%)$ in May, and mean temperature

Table 3. Multiple factorial regressions of climatic variables dissecting genotype $\times$ environment interaction for albumins content

\begin{tabular}{|c|c|c|}
\hline Model & $\begin{array}{l}\text { Environmental variables included } \\
\text { in the final model }\end{array}$ & $\begin{array}{r}\text { Resi- } \\
\text { dual }\end{array}$ \\
\hline \multicolumn{3}{|c|}{ Bread wheat } \\
\hline $\begin{array}{c}\text { All } \\
\text { variables }\end{array}$ & $\mathrm{mt} 3$ (42.3), wmr (26.1), mnt2 (18.6), mnt1 (7.7) & 5.3 \\
\hline March (1) & $\mathrm{mt}$ (32.1), pr (23.3), sh (18.7), mnt (11.3) & 14.5 \\
\hline & $\mathrm{mt}(32.4), \mathrm{rh}(28.0)$, & 7.1 \\
\hline & $\mathrm{mt}(42.3)$, pr (20.6), & 14.5 \\
\hline & rh (40.1), pr (23.4), sh (15.8 & 12.7 \\
\hline \multicolumn{3}{|c|}{ Durum wheat } \\
\hline $\begin{array}{c}\text { All } \\
\text { variables }\end{array}$ & pr2 (31.8), sh1 (25.5), mxt3 (22.7), w & 5.8 \\
\hline March (1) & $\operatorname{rh}(29.6), \operatorname{sh}(26.6), \mathrm{n}$ & 6.0 \\
\hline April (2) & $\operatorname{pr}(31.8), \operatorname{rh}(24.5), \mathrm{mt}(18.9), \operatorname{mnt}(14.8)$ & 9.9 \\
\hline May (3) & $\operatorname{sh}(21.8), \operatorname{pr}(21.5), \mathrm{mt}(19.4), \mathrm{mnt}(12.4)$ & 24.9 \\
\hline June (4) & $\mathrm{mt}(25.3), \mathrm{sh}(20.0), \mathrm{mnt}(16.0), \mathrm{rh}(11.8)$ & 27.0 \\
\hline
\end{tabular}

Notes. All reported values are given as a percentage of sum of squares of explained variance of genotype $\times$ environment interaction by the term. Variable significance is tested against error mean square $P<0.01$. mxt - average maximum temperature, $\mathrm{mnt}$ - average minimum temperature, $\mathrm{mt}$-average mean temperature, pr - precipitation sum, rh - average relative humidity, sh sunshine hours sum, wmr - winter moisture reserves, daily precipitation sum for November-February period.
(25.3\%) in June. According to Garrido-Lestache et al. (2004), large amounts of precipitation in April increased the protein content, and that factor was also recognized as important in our study and included in the final model for durum wheat.

Hurkman et al. (2009) have reported increased level of albumins accumulation and changes in profiles of certain albumins in wheat grains in response to postanthesis high temperature. Marta et al. (2011) found that during the twelve-year period in Tuscany the protein content of durum wheat had a positive and significant correlation with air temperature from March to June $(r=0.568, P<0.05)$, and negative correlation with the precipitation sum from November to February $(r=$ $-0.708, P<0.05)$, which is similar to the results in this paper for bread wheat and durum wheat. In our study, the smaller mean content of albumins for both bread wheat of $19.29 \mathrm{~g} \mathrm{~kg}^{-1}$ and durum wheat of $20.96 \mathrm{~g} \mathrm{~kg}^{-1}$ was recorded in 2010-2011 growing season in regard to higher wmr (179 mm), in comparison to 2011-2012. In the second growing season, the mean albumins content was 21.17 and $21.57 \mathrm{~g} \mathrm{~kg}^{-1}$ for bread wheat and durum wheat genotypes, respectively, and recorded wmr was $149.6 \mathrm{~mm}$. Also, in May and June of 2010-2011 4-8 days were recorded with the maximum temperature higher than $30^{\circ} \mathrm{C}$, while during the $2011-2012$ there were 17-23 days with over $30^{\circ} \mathrm{C}$, depending on the location. The growing season 2011-2012 was warmer at all testlocations, especially during grain filling in June, and with less precipitation during flowering and grain filling (in May and June). Marta et al. (2011) indicated benefit from the formation of local forecasting system for anticipated durum wheat quality based on meteorological forecast for the growing season.

In agreement with our results are those of Hadži-Tašković Šukalović et al. (2013), who found that the wheat protein content was positively correlated with temperature during grain filling, and negatively with precipitation, and also those of Mpofu et al. (2006). The protein content in wheat grain decreases if rainy, cold and wet weather prevails after pollination, but increases if precipitation prevails during vegetative development of wheat, with warm and dry weather during the generative phases (Ceyhan et al., 2011). This was the case in this study during 2011-2012 growing season, when the higher content of albumins was recorded for both bread wheat and durum wheat. Precipitation negatively affects the protein content during grain filling, due to lower nitrogen assimilation and increased assimilation of carbohydrates (Ozturk, Aydin, 2004). Length of wheat grain filling phase is influenced inversely by the air temperature after flowering, and smaller grains appear due to the effects of high temperatures. Similarly, the mass of a thousand grains, as indicator of grain filling, was higher in 2010-2011 for 6.74\% (data not shown), when May and June, when wheat grain filling occurred, had lower average daily temperature by $3.9 \%$ to $6.6 \%$ and higher amount of precipitation by $16.9 \%$ to $33.8 \%$, depending on the location, in relation to the 2011-2012 growing season. The effect of high temperatures reduces the accumulation of total carbohydrates and leads to an increase in protein content due to the smaller grain size and dissolution of assimilated nitrogen, which is associated with the duration of the period when the plant is green after flowering (Kumari, 2011). 


\section{Conclusions}

1. The average albumins content was $12.5 \%$ higher in durum wheat than in bread wheat. The following descending order, by importance, of sources of variation of the albumins content was established: environment, genotype $\times$ environment interaction and genotype. Genotype $\times$ environment interaction (GEI) was greater and heritability in a broad sense estimate much smaller for durum wheat genotypes in comparison to bread wheat genotypes.

2. The obtained models of climatic variables proved their efficiency in explaining GEI for albumins content with over $94 \%$ of sum of squares of explained variance of GEI for bread wheat and durum wheat. They were, respectively: mean temperature in May, winter moisture reserves, minimum temperature in April and March for bread wheat; and precipitation sum in April, sunshine hours sum in March, maximum temperature in May, and winter moisture reserves for durum wheat.

3. The simultaneous selection for high albumins content and good stability is possible for bread wheat genotypes, but not for durum wheat genotypes due to unsatisfactory stability.

\section{Acknowledgements}

The study was supported by the Ministry of Education, Science and Technological Development of the Republic of Serbia within the project TR 31092

Received 17122014

Accepted 23042015

\section{References}

Bezerra C. A., Macedo L. L. P., Amorim T. M. L., Santos V. O., Fragoso R. R., Lucena W. A., Meneguim A. M., Valencia-Jimenez A., Engler G., Silva M. C. M., Albuquerque E. V. S., Grossi-de-Sa M. F. 2014. Molecular cloning and characterization of an $\alpha$-amylase cDNA highly expressed in major feeding stages of the coffee berry borer, Hypothenemus hampei. Gene, 553 (1): 7-16 http://dx.doi.org/10.1016/j.gene.2014.09.050

Ceyhan E., Kahraman A., Önder M. 2011. Environmental effects on quality parameters of plant products. $24^{\text {th }}$ International Conference on Biology, Environment and Chemistry, vol. 24, p. 23-27

Crossa J., Cornelius P. L. 1997. Sites regression and shifted multiplicative model clustering of cultivar trial sites under heterogeneity of error variances. Crop Science, 37: 405-415 http://dx.doi.org/10.2135/cropsci1997.0011183X0037000 $20017 \mathrm{x}$

Denčić S., Mladenov N., Kobiljski B. 2011. Effects of genotype and environment on breadmaking quality in wheat International Journal of Plant Production, 5 (1): 71-82

Falconer D. S. 1996. Introduction to quantitative genetics ( $4^{\text {th }}$ ed. $)$

Garrido-Lestache E., López-Bellido R. J., López-Bellido L. 2004. Effect of $\mathrm{N}$ rate, timing and splitting and $\mathrm{N}$ type on bread-making quality in hard red spring wheat under rainfed Mediterranean conditions. Field Crops Research, 85 (2-3): 213-236 http://dx.doi.org/10.1016/S0378-4290(03)00167-9
Guo G., Lv D., Yan X., Subburaj S., Ge P., Li X., Hu Y., Yan Y. 2012. Proteome characterization of developing grains in bread wheat cultivars (Triticum aestivum L.). BMC Plant Biology, 12: 147 doi:10.1186/1471-2229-12-147 http://dx.doi.org/10.1186/1471-2229-12-147

Hadži-Tašković Šukalović V., Dodig D., Žilić S., Basić Z., Kandić V., Delić N., Miritescu M. 2013. Genotypic and environmental variation of bread and durum wheat proteins and antioxidant compounds. Romanian Agricultural Research, 30: 125-134

Hurkman W. J., Vensel W. H., Tanaka C. K., Whitehand L., Altenbach S. B. 2009. Effect of high temperature on albumin and globulin accumulation in the endosperm proteome of the developing wheat grain. Journal of Cereal Science, 49 (1): 12-23 http://dx.doi.org/10.1016/j.jcs.2008.06.014

Koehler P., Wieser H. 2013. Chemistry of cereal grains. Gobbetti M., Gänzle M. (eds.). Handbook on sourdough biotechnology, p. 11-45

http://dx.doi.org/10.1007/978-1-4614-5425-0_2

Kumari S. 2011. Yield response of uniculm wheat (Triticum aestivum L.) to early and late application of nitrogen: flag leaf development and senescence. Journal of Agricultural Science, 3 (1): 170-182 http://dx.doi.org/10.5539/jas.v3n1p170

Lowry O. H., Rosebrough N. J., Farr A. L., Randall R. J. 1951. Protein measurement with the Folin phenol reagent. Journal of Biological Chemistry, 193 (1): 265-275

Marta A. D., Grifoni D., Mancini M., Zipoli G., Orlandini S. 2011. The influence of climate on durum wheat quality in Tuscany, Central Italy. International Journal of Biometeorology, 55: 87-96 http://dx.doi.org/10.1007/s00484-010-0310-8

Mpofu A., Harry D., Sapirstein H. D., Beta T. 2006. Genotype and environmental variation in phenolic content, phenolic acid composition, and antioxidant activity of hard spring wheat. Journal of Agricultural and Food Chemistry, 54: 1265-1270 http://dx.doi.org/10.1021/jf052683d

Muralikrishna G., Nirmala M. 2005. Cereal alpha-amylases an overview. Carbohydrate Polymers, 60: 163-173 http://dx.doi.org/10.1016/j.carbpol.2004.12.002

Ozturk A., Aydin F. 2004. Effect of water stress at various growth stages on some quality characteristics of winter wheat. Journal of Agronomy and Crop Science, 190 (2): 93-99 http://dx.doi.org/10.1046/j.1439-037X.2003.00080.x

Palosuo T., Kersebaum K. C., Angulo C., Hlavinka P., Moriondo M., Olesen J. E., Patil R. H., Ruget F., Rumbaur C., Takáč J., Trnka M., Bindi M., Çaldağ B., Ewert F., Ferrise R., Mirschel W., Şaylan L., Šiška B., Rötter R. 2011. Simulation of winter wheat yield and its variability in different climates of Europe: a comparison of eight crop growth models. European Journal of Agronomy, 35 (3): $103-114$ http://dx.doi.org/10.1016/j.eja.2011.05.001

Pan J., Zhu Y., Cao W., Dai T., Jiang D. 2006. Predicting the protein content of grain in winter wheat with meteorological and genotypic factors. Plant Production Science, 9 (3): 323-333 http://dx.doi.org/10.1626/pps.9.323

Piasecka-Kwiatkowska D., Madaj D., Warchalewski J. R. 2007. The biological activity of wheat, rye and triticale varieties harvested in four consecutive years. Scientiarum Polonorum Technologia Alimentaria, 6 (4): 55-65

Piergiovanni A. R. 2007. Extraction and separation of watersoluble proteins from different wheat species by acidic capillary electrophoresis. Journal of Agricultural Food Chemistry, 55: 3850-3856 http://dx.doi.org/10.1021/jf063628n 
R Core Team 2013. R: a language and environment for statistical computing. R Foundation for Statistical Computing. $<$ http://www.R-project.org> [accessed 2012 2014]

StatSoft 2009. STATISTICA for windows. StatSoft Inc., Tulsa, USA

Tao H., Ma J., Liu C., You W., Yan M., Wang B. 2012. Distribution of protein components of wheat from different regions. African Journal of Biotechnology, 11 (46): 10568 10574

van Eeuwijk F. A., Denis J.-B., Kang M. S. 1996. Incorporating additional information on genotypes and environments in models for two-way genotype by environment tables. Kang M. S., Gauch H. G. Jr. (eds). Genotype-by-environment interaction, chapter 2, p. 15-49

http://dx.doi.org/10.1201/9781420049374.ch2
World reference base for soil resources 2014. International soil classification system for naming soils and creating legends for soil maps. Food and Agriculture Organization of the United Nations, Rome, Italy, $106 \mathrm{p}$.

Yan M. L., Cai R. G., Jia X. L., Wang J. C., Wang Z. L. 2007. Efects of different irrigation regimes on protein components and dough rheology of wheat. Acta Agronomica Sinica, 33: $337-340$

Yu Z., Han C., Wang S., Lv D., Chen G., Li X., Jiang G. L., Yan Y. 2013. Fast separation and characterization of watersoluble proteins in wheat grains by reversed-phase ultra performance liquid chromatography (RP-UPLC). Journal of Cereal Science, 57: 288-294

http://dx.doi.org/10.1016/j.jcs.2012.11.008

ISSN 1392-3196 / e-ISSN 2335-8947

Zemdirbyste-Agriculture, vol. 102, No. 3 (2015), p. 281-288

DOI $10.13080 /$ z-a.2015.102.036

\title{
Aplinkos įtaka duoninių (Triticum aestivum L.) ir kietụjų (Triticum durum Desf.) kviečių albuminų kiekiui
}

\author{
G. Branković1 , V. Dragičević , D. Dodig ${ }^{2}$, D. Knežević ${ }^{3}$ B. Kobiljski ${ }^{4}$, G. Šurlan-Momirović ${ }^{1}$ \\ ${ }^{1}$ Belgrado universitetas, Serbija \\ ${ }^{2}$ Serbijos ,Zemun Polje“ kukurūzų tyrimo institutas \\ ${ }^{3}$ Prištinos universitetas, Serbija \\ ${ }^{4}$ Biogranum Ltd., Serbija
}

\section{Santrauka}

Kviečiuose esantys albuminai, arba vandenyje tirpūs baltymai, yra svarbūs kaip maistingosios medžiagos, turinčios dideli kiekį nepakeičiamųjų amino rūgščių - lizino, triftofano, metionino, taip pat asparagino, glutamino, arginino ir prolino, palyginus su atsarginiais baltymais - gluteninais ir gliadinais. Siekiant nustatyti albuminų kiekị grūduose, penkiolika duoninių ir tiek pat kietujų kviečių genotipų buvo vertinti dvejus metus šešiose skirtingose aplinkose. Tyrimo tikslas - taikant klimato veiksnių modeliavimą nustatyti albuminų kiekio svyravimus tirtuose duoninių ir kietujų kviečių genotipuose, aplinkos ir genotipo ịtaką ir jų sąveiką, paveldimumą plačiąja prasme, stabilumą, taip pat interpretuoti genotipo ir aplinkos sąveiką. Statistinè analizè buvo atlikta taikant dispersinę analizę ir vietų bei faktorinę regresiją. Vidutinis albuminų kiekis duoniniuose kviečiuose buvo $20,23 \mathrm{~g} \mathrm{~kg}^{-1}$, kietuosiuose kviečiuose - 23,12 g kg-1. Pagrindiniai veiksniai, nulèmę albuminų kiekį, buvo aplinka ir genotipo bei aplinkos sąveika. Paveldimumas plačiaja prasme buvo nedidelis - 31,3\% duoniniams kviečiams ir tik 2,4 \% kietiesiems kviečiams. Genotipo ir aplinkos sąveika albuminų kiekiui buvo paaiškinta 94,7 \% ir 94,2 \% kvadratų sumos efektyvumu atitinkamai duoniniams ir kietiesiems kviečiams, taikant šiuos modelius: vidutinès gegužès mėnesio temperatūros, drègmès atsargos žiemos metu, minimalios balandžio bei kovo mėnesių temperatūros duoniniams kviečiams ir balandžio mėnesio kritulių sumos, saulès švytėjimo valandų sumos kovo mènesị, maksimalios temperatūros gegužès mėnesị bei drègmès atsargos žiemos metu kietiesiems kviečiams. Atranka dideliam kiekiui albuminų ir stabilumui pasirodè tinkama duoninių kviečių genotipams, tačiau mažiau tinkama kietiesiems kviečiams dèl nepakankamo stabilumo.

Reikšminiai žodžiai: faktorinè regresija, genotipo ir aplinkos sąveika, grūdų kokybė, kelių aplinkų bandymai, paveldimumas. 